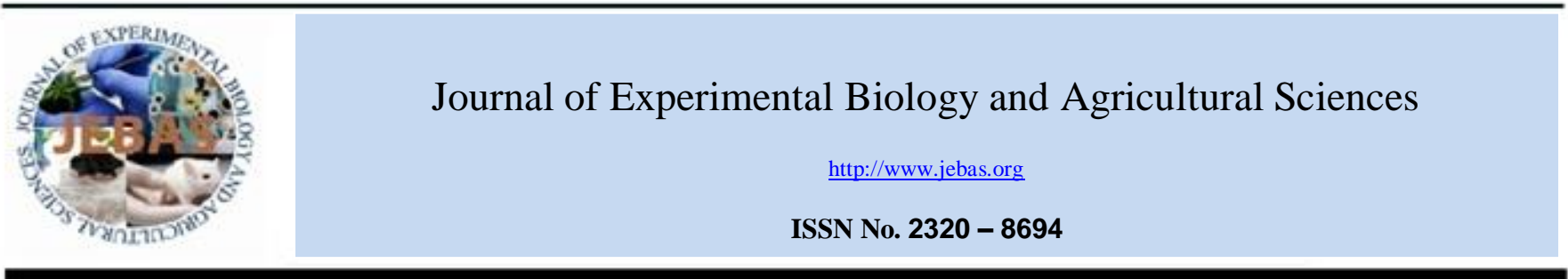

\title{
EVALUATING POSTEMERGENCE HERBICIDES FOR BROADLEAF WEED CONTROL IN IRRIGATED BREAD WHEAT (Triticum aestivum L.)
}

\author{
Abbès Tanji ${ }^{1, *}$, Yahya Baye ${ }^{2}$, Mohamed Boutfirass ${ }^{3}$ \\ ${ }^{1}$ Retired weed scientist, Farah 1, Rue Kacem Amine No 1, 26002 Settat, Morocco \\ ${ }^{2}$ Institut National de la Recherche Agronomique, Béni Mellal, Morocco \\ ${ }^{3}$ Institut National de la Recherche Agronomique, Settat, Morocco \\ Received - September 10, 2017; Revision - October 14, 2017; Accepted - October 24, 2017 \\ Available Online - October 31, 2017 \\ http://dx.doi.org/10.18006/2017.5(5).614.622
}

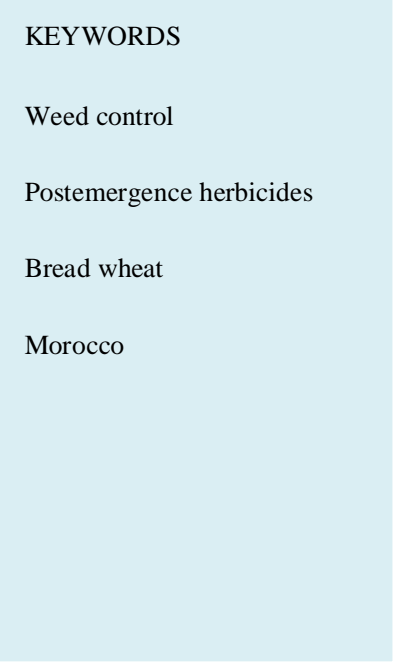

* Corresponding author

E-mail: abbestanji1@gmail.com (Abbès Tanji)

Peer review under responsibility of Journal of Experimental Biology and Agricultural Sciences.

Production and Hosting by Horizon Publisher India [HPI] (http://www.horizonpublisherindia.in/).

All rights reserved.

\begin{abstract}
The objective of this research was to study the effect of broadleaf herbicide treatments and grass + broadleaf herbicides on annual broadleaf weeds and bread wheat yield. Eight on-farm weed control trials were conducted in bread wheat from 2014-15 to 2016-17 in Tadla and Doukkala irrigated perimeters, Morocco: 3 trials using broadleaf herbicides and 5 trials using premix or tank mix of grass and broadleaf herbicides. In 3 trials, 9 broadleaf herbicides (metsulfuron-methyl $6 \mathrm{~g} \mathrm{ha}^{-1}$, tribénuronmethyl $9.375 \mathrm{~g} \mathrm{ha}^{-1}$, amidosulfuron $15 \mathrm{~g} \mathrm{ha}^{-1}+$ iodosulfuron-methyl-sodium $3.75 \mathrm{~g} \mathrm{ha}^{-1}$, aminopyralid $9.9 \mathrm{~g} \mathrm{ha}^{-1}+$ florasulam $4.95 \mathrm{~g} \mathrm{ha}^{-1}$, dicamba $120 \mathrm{~g} \mathrm{ha}^{-1}+2,4-\mathrm{D} 344 \mathrm{~g} \mathrm{ha}^{-1}$, florasulam $3.75 \mathrm{~g} \mathrm{ha}^{-1}+2,4-\mathrm{D}$ $180 \mathrm{~g} \mathrm{ha}^{-1}$, flumetsulam $5 \mathrm{~g} \mathrm{ha}^{-1}+$ florasulam $3.75 \mathrm{~g} \mathrm{ha}^{-1}$, triasulfuron $6.15 \mathrm{~g} \mathrm{ha}^{-1}+$ dicamba $98.85 \mathrm{~g} \mathrm{ha}^{-1}$, and tribenuron-methyl $5 \mathrm{~g} \mathrm{ha}^{-1}+$ thifensulfuron-methyl $10 \mathrm{~g} \mathrm{ha}^{-1}$ ) caused no injury to bread wheat, reduced 80 to $100 \%$ density and shoot biomass of broadleaf weeds, and provided wheat grain yields up to 8.0 Tons $\mathrm{ha}^{-1}$ compared to the untreated plots. In 5 trials, 12 premix or tank mix of grass and broadleaf herbicides reduced shoot biomass of broadleaf weeds up to $100 \%$ and provided wheat grain yields up to 9.3 Tons $\mathrm{ha}^{-1}$ compared to the untreated plots. Herbicide treatments containing pyroxsulam or mesosulfuron-methyl + iodosulfuron-methyl-sodium caused crop injury, but wheat plants recovered and grain yield was not affected.
\end{abstract}

All the article published by Journal of Experimental Biology and Agricultural Sciences is licensed under a Creative Commons Attribution-NonCommercial 4.0 International License Based on a work at www.jebas.org.

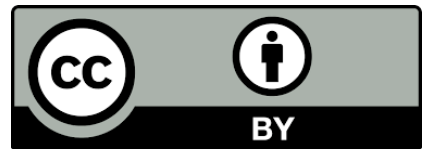


Mesosulfuron-methyl + iodosulfuron-methyl-sodium and mesosulfuron-methyl + iodosulfuronmethyl-sodium + diflufenican were less effective on milk thistle (Silybum marianum (L.) Gaertn). Further research involving grass and broadleaf herbicides is needed to explore ways, including the use of adjuvants, to avoid wheat injury and optimize herbicide efficacy on noxious weeds such as milk thistle.

\section{Introduction}

Bread wheat (Triticum aestivum L.) is a major crop that is grown on 2 million hectares in Morocco (Rerhrhaye \& Ait El Mekki, 2017). Out of this, about 200,000 hectares are cultivated under irrigation. Irrigated bread wheat is usually planted in November in rotation with several crops including sugarbeet (Beta vulgaris L.), corn (Zea mays L.), Egyptian clover (Trifolium alexandrinum L.) or alfalfa (Medicago sativa L.). In 2015-16, grain yield of irrigated bread wheat was estimated to 4 Tons $^{-1}{ }^{-1}$ (Rerhrhaye \& Ait El Mekki, 2017), but area and yield increases over the past decades have been minimal. However, Jlibene \& Chafai Elalaoui (2002) found that some bread wheat cultivars, when cultivated appropriately under irrigation, produced up to $7.8 \mathrm{Tons} \mathrm{ha}^{-1}$.

More than 300 weed species have been identified in wheat fields (Taleb et al., 2000). Among them, major annual grass weeds are rigid brome (Anisantha rigida (Roth) Hyl.), sterile oat (Avena sterilis L.), canarygrass (Phalaris brachystachys Link, P. minor Retz., P. paradoxa L.), and rigid ryegrass (Lolium rigidum Gaud.) (Tanji, 2005). Major annual broadleaf weeds are common poppy (Papaver rhoeas L.), milk thistle (Silybum marianum (L.) Gaertn.), wild mustard (Sinapis arvensis L.), wild chicory (Cichorium intybus L.), spiny emex (Emex spinosa (L.) Campd.), and crown daisy (Glebionis coronaria (L.) Spach) (Tanji, 2005). All these weeds are fall and/or winter annuals, and the weed emergence pattern is a consequence of soil moisture (from rainfall and irrigation) and germination temperature requirements. In 23 weed control trials, Tanji (2002) found that weed densities in the untreated plots were up to 500 plants $\mathrm{m}^{-2}$, and grain yield losses of irrigated bread wheat due to weed competition were up to $80 \%$.

Weed control with herbicides is the most common practice in irrigated wheat (Tanji, 2000). Furthermore, Tanji (2003) reported that tribenuron-methyl $\left(9.375 \mathrm{~g} \mathrm{ha}^{-1}\right)$, triasulfuron + terbutryne (10 $\left.+150 \mathrm{~g} \mathrm{ha}^{-1}\right)$, and 2,4-D + MCPA $\left(330+341 \mathrm{~g} \mathrm{ha}^{-1}\right)$ provided up to $96 \%$ control of annual broadleaf weeds. In general, the use of selective postemergence herbicides resulted in excellent weed control and increased bread wheat yield (Benahnia, 1985; Rafrafi, 1988; Errohi, 1995; Aitounejjar \& Tanji, 1997; Benslimane, 2000; Tanji, 2002; Tanji, 2003; El Antri \& Madkouri, 2005).
Since 2000, several postemergence herbicides (amidosulfuron, aminopyralid, flucarbazon, iodosulfuron-methyl-sodium, mesosulfuron-methyl, metsulfuron-methyl, pyroxsulam, thifensulfuron-methyl, and many others) have been registered in Morocco for weed control in wheat. However, limited research has been conducted on weed control with these recently registered herbicides in irrigated wheat. Information on herbicide choice, effective herbicide application rates, and application timing is needed to provide producers with precise decision tools for managing weeds in wheat production systems. The objective of this study was to evaluate the response of annual broadleaf weeds and wheat production to 9 broadleaf herbicide treatments in 3 trials and 12 premix or tank mix of grass and broadleaf herbicide treatments in irrigated bread wheat in 5 trials.

\section{Materials and Methods}

\subsection{Experiment site and design}

A total of 8 bread wheat trials were conducted in farmers' fields from 2014-15 to 2016-17, in Doukkala and Tadla perimeters, Morocco: 3 trials using postemergence broadleaf herbicides (Tables $1 \& 2$ ) and 5 trials using premix or tank mix of postemergence grasss and broadleaf herbicides (Tables $1 \& 3$ ). The preceding crops were alfalfa, faba bean, sugar beet or bread wheat. Fields were plowed once with a deep plow and twice with a tandem disc. Each field measured 1 hectare that was drilled with "Amal" bread wheat at a seed rate of $200 \mathrm{~kg} \mathrm{ha}^{-1}$ in November 2014, 2015, and 2016. The N-P-K fertilizer used at planting was either diammonium phosphate (18-46-0) at the rate of $200 \mathrm{~kg} \mathrm{ha}^{-1}$ or 15-15-15 at the rate of $300 \mathrm{~kg} \mathrm{ha}^{-1}$. It was manually broadcast and incorporated with a tandem disc before planting. After crop emergence, ammonium nitrate $33 \%$ was broadcast 2 to 3 times during the growing season. Trials had access to irrigation to supplement rainfall (Table 1).

Trials were arranged as randomized complete blocks with 3 replications and individual plot size measured $10 \mathrm{~m}$ by 2 to $3 \mathrm{~m}$. One nontreated control per replication was included for treatment comparisons. At the early wheat tillering stage, 9 broadleaf herbicide treatments (Table 2) and 12 premix or tank mix of grass and broadleaf herbicide treatments were applied (Table 3). The herbicides and their rates were 
Table 1 Characteristics of the 8 on-farm trials conducted from 2014-15 to 2016-17 in the Tadla and Doukkala irrigated perimeters, Morocco

\begin{tabular}{|c|c|c|c|c|c|c|c|c|}
\hline \multirow[b]{2}{*}{$\begin{array}{l}\text { Management } \\
\text { practices }\end{array}$} & \multicolumn{3}{|c|}{3 trials with broadleaf herbicides } & \multicolumn{5}{|c|}{5 trials with premix or tank mix of grass and broadleaf herbicides } \\
\hline & $\begin{array}{c}\text { Tadla } \\
\text { 2014-15 } \\
\text { Trial } 1\end{array}$ & $\begin{array}{c}\text { Tadla } \\
\text { 2015-16 } \\
\text { Trial } 2\end{array}$ & $\begin{array}{c}\text { Doukkala } \\
\text { 2015-16 } \\
\text { Trial } 3\end{array}$ & $\begin{array}{c}\text { Tadla } \\
\text { 2014-15 } \\
\text { Trial } 1\end{array}$ & $\begin{array}{c}\text { Tadla } \\
\text { 2015-16 } \\
\text { Trial } 2\end{array}$ & $\begin{array}{c}\text { Tadla } \\
\text { 2016-17 } \\
\text { Trial } 3\end{array}$ & $\begin{array}{c}\text { Tadla } \\
\text { 2016-17 } \\
\text { Trial } 4\end{array}$ & $\begin{array}{c}\text { Doukkala } \\
\text { 2015-16 } \\
\text { Trial } 5\end{array}$ \\
\hline Preceding crop & sugarbeet & alfalfa & sugarbeet & sugarbeet & sugarbeet & sugarbeet & faba bean & sugarbeet \\
\hline Tillage & $\begin{array}{c}1 \text { deep plowing } \\
+2 \text { tandem disc } \\
+ \text { planting with a } \\
\text { drill } \\
\end{array}$ & $\begin{array}{c}1 \text { deep plowing } \\
+2 \text { tandem disc } \\
+ \text { planting with a } \\
\text { drill } \\
\end{array}$ & $\begin{array}{c}1 \text { deep plowing } \\
+2 \text { tandem disc } \\
+ \text { planting with a } \\
\text { drill } \\
\end{array}$ & $\begin{array}{c}1 \text { deep plowing } \\
+2 \text { tandem disc } \\
+ \text { planting with a } \\
\text { drill } \\
\end{array}$ & $\begin{array}{c}1 \text { deep plowing } \\
+2 \text { tandem disc } \\
+ \text { planting with a } \\
\text { drill } \\
\end{array}$ & $\begin{array}{c}1 \text { deep plowing } \\
+2 \text { tandem disc } \\
+ \text { planting with a } \\
\text { drill } \\
\end{array}$ & $\begin{array}{c}1 \text { deep plowing } \\
+2 \text { tandem disc } \\
+ \text { planting with a } \\
\text { drill } \\
\end{array}$ & $\begin{array}{c}1 \text { deep plowing } \\
+2 \text { tandem disc } \\
+ \text { planting with a } \\
\text { drill } \\
\end{array}$ \\
\hline $\begin{array}{l}\text { Date of } \\
\text { planting }\end{array}$ & Nov 20, 2014 & Nov 22, 2015 & Nov 20, 2015 & Nov 22, 2014 & Nov 20, 2015 & Nov 15, 2016 & Nov 21, 2016 & Nov 20, 2015 \\
\hline $\begin{array}{l}\text { Date of crop } \\
\text { emergence }\end{array}$ & Nov 29, 2014 & Dec 1, 2015 & Dec 1, 2015 & Dec 1, 2014 & Nov 29, 2015 & Nov 21, 2016 & Nov 28, 2016 & Dec 1, 2015 \\
\hline $\begin{array}{l}\text { Fertilizer at } \\
\text { planting }\end{array}$ & $\begin{array}{l}200 \mathrm{~kg} \mathrm{ha}^{-1} \\
\text { DAP } 18-46-0\end{array}$ & $\begin{array}{l}200 \mathrm{~kg} \mathrm{ha}^{-1} \\
\text { DAP } 18-46-0\end{array}$ & $\begin{array}{l}300 \mathrm{~kg} \mathrm{ha}^{-1} \\
15-15-15\end{array}$ & $\begin{array}{l}200 \mathrm{~kg} \mathrm{ha}^{-1} \\
\text { DAP } 18-46-0\end{array}$ & $\begin{array}{l}200 \mathrm{~kg} \mathrm{ha}^{-1} \\
\text { DAP } 18-46-0\end{array}$ & $\begin{array}{c}200 \mathrm{~kg} \mathrm{ha}^{-1} \\
\text { DAP } 18-46-0\end{array}$ & $\begin{array}{l}200 \mathrm{~kg} \mathrm{ha}^{-1} \\
\text { DAP } 18-46-0\end{array}$ & $\begin{array}{c}300 \mathrm{~kg} \mathrm{ha}^{-1} \\
15-15-15\end{array}$ \\
\hline $\begin{array}{l}\text { Top dressing } \\
\text { nitrogen }\end{array}$ & $\begin{array}{c}100 \mathrm{~kg} \mathrm{ha}^{-1} \\
\text { ammonium nitrate } \\
33 \% \text { at the tillering } \\
\text { stage, } \\
100 \mathrm{~kg} \mathrm{ha}^{-1} \\
\text { ammonium nitrate } \\
33 \% \text { at the jointing } \\
\text { stage }\end{array}$ & $\begin{array}{c}100 \mathrm{~kg} \mathrm{ha}^{-1} \\
\text { ammonium nitrate } \\
33 \% \text { at the tillering } \\
\text { stage, } \\
100 \mathrm{~kg} \mathrm{ha}^{-1} \\
\text { ammonium nitrate } \\
33 \% \text { at the jointing } \\
\text { stage }\end{array}$ & $\begin{array}{c}100 \mathrm{~kg} \mathrm{ha}^{-1} \\
\text { ammonium nitrate } \\
33 \% \text { at the tillering } \\
\text { stage, } \\
100 \mathrm{~kg} \mathrm{ha}^{-1} \\
\text { ammonium nitrate } \\
33 \% \text { at the jointing } \\
\text { stage }\end{array}$ & $\begin{array}{c}100 \mathrm{~kg} \mathrm{ha}^{-1} \\
\text { ammonium nitrate } \\
33 \% \text { at the tillering } \\
\text { stage, } \\
100 \mathrm{~kg} \mathrm{ha}^{-1} \\
\text { ammonium nitrate } \\
33 \% \text { at the jointing } \\
\text { stage }\end{array}$ & $\begin{array}{c}100 \mathrm{~kg} \mathrm{ha}^{-1} \\
\text { ammonium nitrate } \\
33 \% \text { at the tillering } \\
\text { stage, } \\
100 \mathrm{~kg} \mathrm{ha}^{-1} \\
\text { ammonium nitrate } \\
33 \% \text { at the jointing } \\
\text { stage }\end{array}$ & $\begin{array}{c}200 \mathrm{~kg} \mathrm{ha}^{-1} \\
\text { ammonium nitrate } \\
33 \% \text { at the tillering } \\
\text { stage, } \\
150 \mathrm{~kg} \mathrm{ha}^{-1} \\
\text { ammonium nitrate } \\
33 \% \text { at the jointing } \\
\text { stage }\end{array}$ & $\begin{array}{c}200 \mathrm{~kg} \mathrm{ha}^{-1} \\
\text { ammonium nitrate } \\
33 \% \text { at the tillering } \\
\text { stage, } \\
150 \mathrm{~kg} \mathrm{ha}^{-1} \\
\text { ammonium nitrate } \\
33 \% \text { at the jointing } \\
\text { stage }\end{array}$ & $\begin{array}{c}100 \mathrm{~kg} \mathrm{ha}^{-1} \\
\text { ammonium nitrate } \\
33 \% \text { at the tillering } \\
\text { stage, } \\
100 \mathrm{~kg} \mathrm{ha}^{-1} \\
\text { ammonium nitrate } \\
33 \% \text { at the jointing } \\
\text { stage }\end{array}$ \\
\hline $\begin{array}{l}\text { Foliar fungicide } \\
\text { at the booting } \\
\text { stage and } \\
\text { repeated at } \\
\text { heading }\end{array}$ & $\begin{array}{l}\text { spiroxamine } \\
200 \mathrm{~g} \mathrm{ha}^{-1} \\
+ \text { tebuconazole } \\
133.6 \mathrm{~g} \mathrm{ha}^{-1} \\
+ \text { triadimenol } \\
34.4 \mathrm{~g} \mathrm{ha}^{-1}\end{array}$ & $\begin{array}{c}\text { spiroxamine } \\
200 \mathrm{~g} \mathrm{ha}^{-1} \\
+ \text { tebuconazole } \\
133.6 \mathrm{~g} \mathrm{ha}^{-1} \\
+ \text { triadimenol } \\
34.4 \mathrm{~g} \mathrm{ha}^{-1} \\
\end{array}$ & $\begin{array}{c}\text { spiroxamine } \\
200 \mathrm{~g} \mathrm{ha}^{-1} \\
+ \text { tebuconazole } \\
133.6 \mathrm{~g} \mathrm{ha}^{-1} \\
+ \text { triadimenol } \\
34.4 \mathrm{~g} \mathrm{ha}^{-1} \\
\end{array}$ & $\begin{array}{c}\text { spiroxamine } \\
200 \mathrm{~g} \mathrm{ha}^{-1} \\
+ \text { tebuconazole } \\
133.6 \mathrm{~g} \mathrm{ha}^{-1} \\
+ \text { triadimenol }^{-1} \\
34.4 \mathrm{~g} \mathrm{ha}^{-1}\end{array}$ & $\begin{array}{l}\text { spiroxamine } \\
200 \mathrm{~g} \mathrm{ha}^{-1} \\
+ \text { tebuconazole } \\
133.6 \mathrm{~g} \mathrm{ha}^{-1} \\
+ \text { triadimenol } \\
34.4 \mathrm{~g} \mathrm{ha}^{-1}\end{array}$ & $\begin{array}{c}\text { spiroxamine } \\
200 \mathrm{~g} \mathrm{ha}^{-1} \\
+ \text { tebuconazole } \\
133.6 \mathrm{~g} \mathrm{ha}^{-1} \\
+ \text { triadimenol }^{-1} \\
34.4 \mathrm{~g} \mathrm{ha}^{-1}\end{array}$ & $\begin{array}{c}\text { Spiroxamine } \\
200 \mathrm{~g} \mathrm{ha}^{-1} \\
+ \text { tebuconazole } \\
133.6 \mathrm{~g} \mathrm{ha}^{-1} \\
+ \text { triadimenol } \\
34.4 \mathrm{~g} \mathrm{ha}^{-1} \\
\end{array}$ & $\begin{array}{c}\text { spiroxamine } 200 \mathrm{~g} \\
\text { ha }^{-1} \\
+ \text { tebuconazole } \\
133.6 \mathrm{~g} \mathrm{ha}^{-1} \\
+ \text { triadimenol } 34.4 \mathrm{~g} \\
\mathrm{ha}^{-1}\end{array}$ \\
\hline $\begin{array}{l}\text { Irrigation } \\
\text { system }\end{array}$ & Flood irrigation & Flood irrigation & Flood irrigation & Flood irrigation & Flood irrigation & Flood irrigation & Flood irrigation & Flood irrigation \\
\hline $\begin{array}{c}\text { Date of } \\
\text { spraying weed } \\
\text { control trials }\end{array}$ & $\begin{array}{l}\text { Dec 30, } 2014 \text { at the } \\
\text { tillering stage }\end{array}$ & $\begin{array}{l}\text { Jan 2, } 2016 \text { at the } \\
\text { tillering stage }\end{array}$ & $\begin{array}{l}\text { Jan 7, } 2016 \text { at the } \\
\text { tillering stage }\end{array}$ & $\begin{array}{l}\text { Jan } 6,2015 \text { at the } \\
\text { tillering stage }\end{array}$ & $\begin{array}{l}\text { Jan 3, } 2016 \text { at the } \\
\text { tillering stage }\end{array}$ & $\begin{array}{l}\text { Jan } 1,2017 \text { at the } \\
\text { tillering stage }\end{array}$ & $\begin{array}{l}\text { Jan } 10,2017 \text { at the } \\
\text { tillering stage }\end{array}$ & $\begin{array}{l}\text { Jan } 8,2016 \text { at the } \\
\text { tillering stage }\end{array}$ \\
\hline
\end{tabular}

Journal of Experimental Biology and Agriculture Science

http://www.jebas.org 
Table 2 Effect of broadleaf herbicides on the density and shoot dry weight (DW) of broadleaf weeds 2 months after treatment (2 MAT), and bread wheat grain yield in 3 on-farm weed control trials in 2014-15 and 2015-16 in the Tadla and Doukkala irrigated perimeters, Morocco

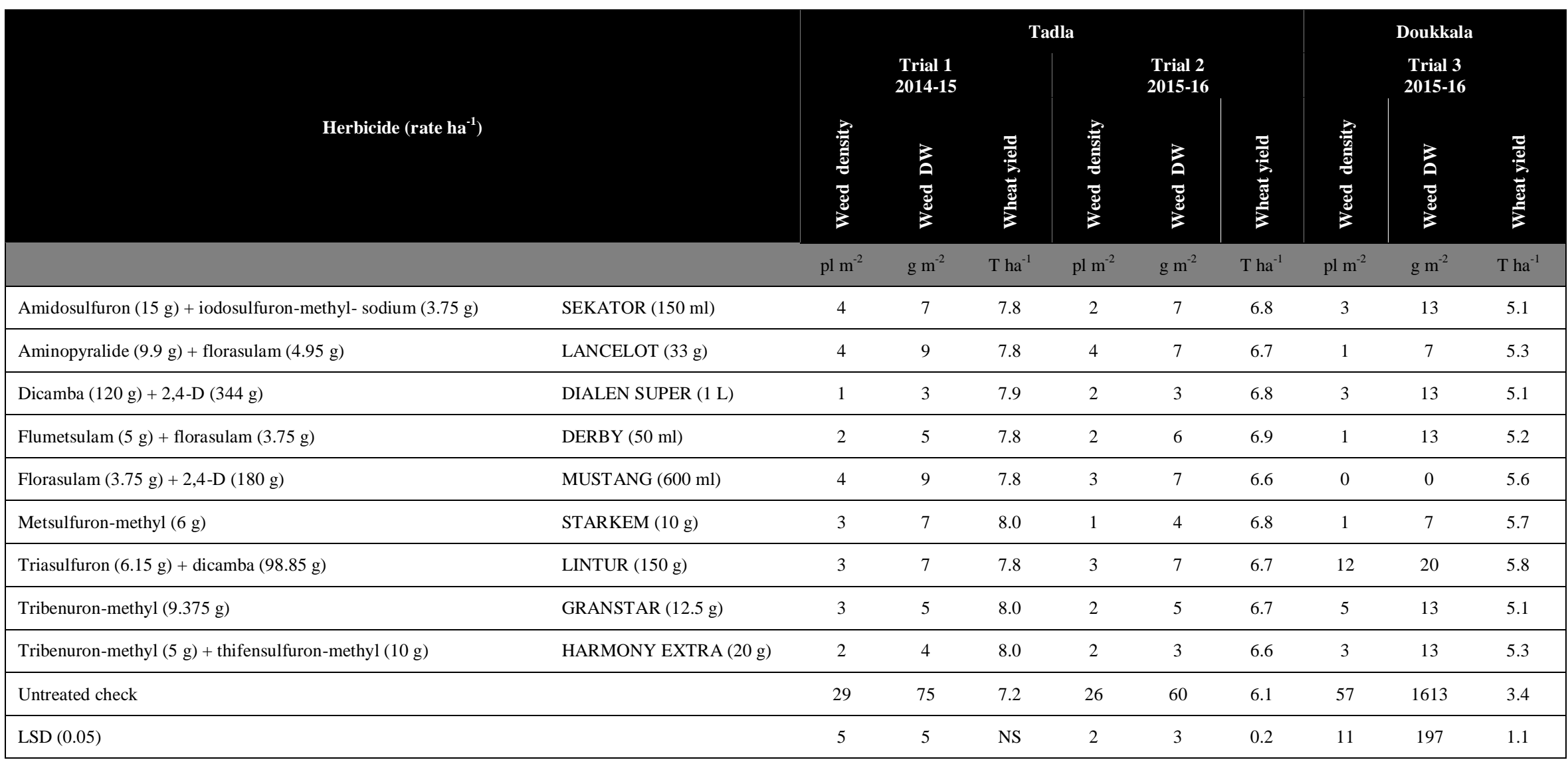


Table 3 Effect of premix or tank mix of grass and broadleaf herbicides on the density and shoot dry weight (DW) of broadleaf weeds 2 months after treatment ( 2 MAT) and wheat grain yield in 5 on-farm weed control trials from 2014-15 to 2016-17 in the Tadla and Doukkala irrigated perimeters, Morocco

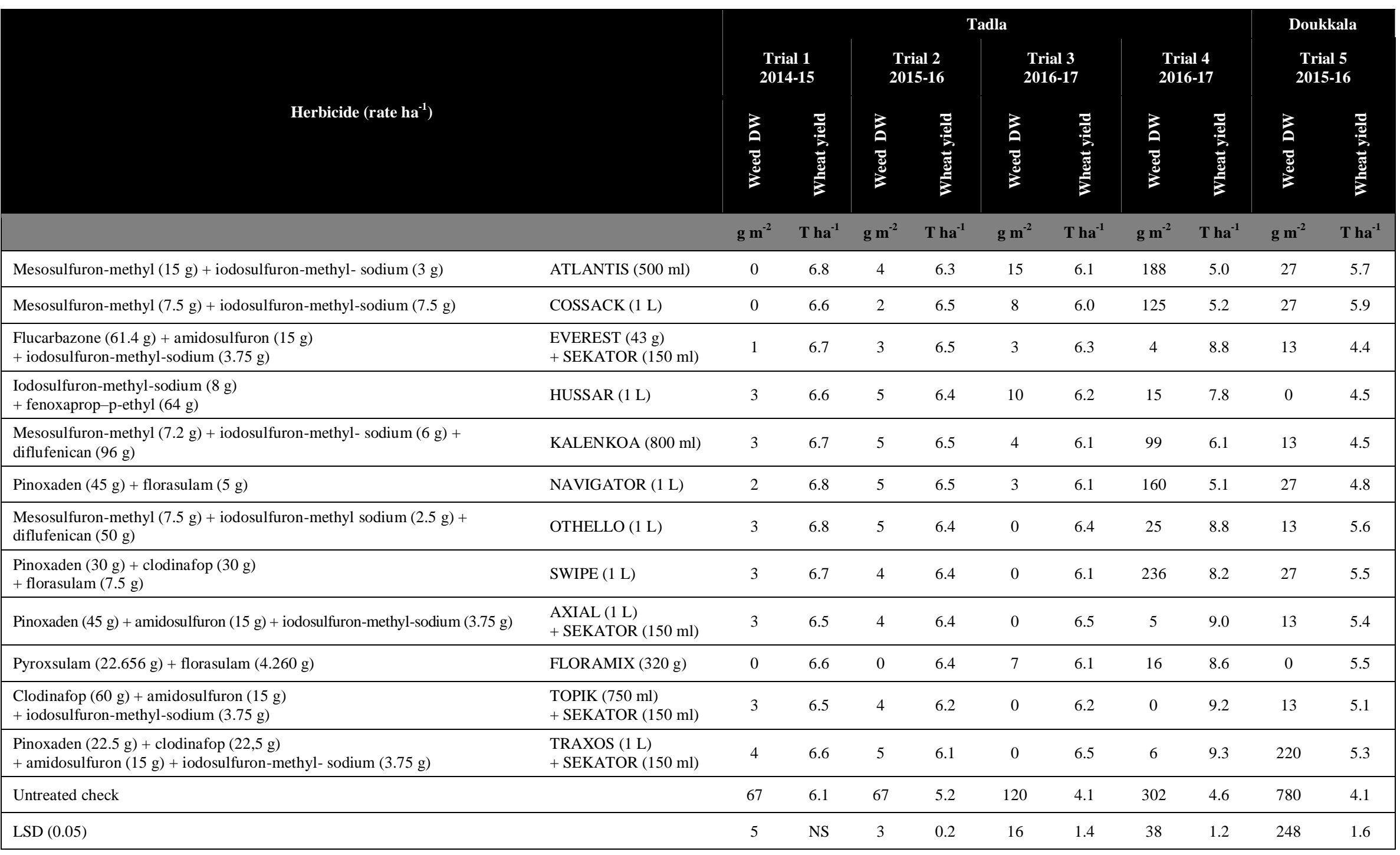

Journal of Experimental Biology and Agriculture Science

http://www.jebas.org 
recommended field rates for weed control in wheat (Tables 2 and 3). In the 3 trials with broadleaf herbicides, major weed species infesting wheat included spiny emex (E. spinosa), common poppy (Papaver rhoeas L.), nettleleaf goosefoot (Chenopodium murale), wild mustard (S. arvensis), wild chicory (C. intybus), common sowthistle (Sonchus oleraceus), and henbit (Lamium amplexicaule). In the 5 trials with grass and broadleaf herbicides, major weed species infesting wheat were milk thistle (S. marianum), field marigold (Calendula arvensis), wild mustard (S. arvensis), wild chicory (C. intybus), and blue pimpernel (Lysimachia arvensis).

Herbicide application was done at the seedling or vegetative stage of broadleaf weeds. Foliar fungicides were sprayed at the boot stage and repeated at heading. Herbicide and fungicide treatments were applied with a backpack sprayer fitted with a spray boom with 4 flat fan 8002 nozzles calibrated to deliver $200 \mathrm{~L} \mathrm{ha}^{-1}$.

\subsection{Measurements}

Two months after treatments ( 2 MAT), weeds were collected from one $0.50 \mathrm{~m} \times 0.50 \mathrm{~m}$ quadrat in each plot. Removed weeds were counted for density, and shoots were oven dried at $60^{\circ} \mathrm{C}$ to a constant weight and weighed. At full maturity, wheat was harvested at ground level in an area of $1 \mathrm{~m}^{2}$ per plot. Wheat was threshed by a small combine and grain was cleaned and weighed. Wheat yield loss due to weed competition and yield increase due to herbicide use were calculated as follows:

\%yield loss $=\frac{\left(\begin{array}{c}\text { Grain yield in weed }- \text { free plots } \\ - \text { Grain yield in weedy plots }\end{array}\right)}{\text { Grain yield in weed }- \text { free plots }} \times 100$

\subsection{Statistical analyses}

Measured variables (weed density, weed shoot dry weight, and wheat grain yield) varied across trials and cropping seasons, primarily due to differences in environmental conditions (irrigation, rainfall, soil type, crop rotation). Therefore, data analysis was performed for each trial to determine the significance of the herbicide treatments. Density and biomass of weeds and wheat grain yields were subjected to the ANOVA using SAS (SAS Institute, Cary, NC, USA). Means were compared using the Fisher's protected LSD at $\mathrm{P}=0.05$.

\section{Results and Discussion}

\subsection{Weed control with broadleaf herbicides ( 3 trials)}

Weed densities in untreated plots varied from 26 to 57 plants $\mathrm{m}^{-2}$ (Table 2). Shoot dry weights varied between 60 and $1613 \mathrm{~g} \mathrm{~m}^{-2}$. Five herbicide treatments viz. (i) metsulfuron-methyl $6 \mathrm{~g} \mathrm{ha}^{-1}$, (ii) tribenuron-methyl $9.375 \mathrm{~g} \mathrm{ha}^{-1}$, (iii) dicamba $120 \mathrm{~g} \mathrm{ha}^{-1}+2,4-\mathrm{D}$ $344 \mathrm{~g} \mathrm{ha}^{-1}$, (iv) flumetsulam $5 \mathrm{~g} \mathrm{ha}^{-1}+$ florasulam $3.75 \mathrm{~g} \mathrm{ha}^{-1}$, and (v) tribenuron-methyl $5 \mathrm{~g} \mathrm{ha}^{-1}+$ thifensulfuron-methyl $10 \mathrm{~g} \mathrm{ha}^{-1}$ provided consistently excellent weed control by reducing weed density and/or weed biomass by $\geq 90 \%$. While the other herbicide treatments i.e. (i) amidosulfuron $15 \mathrm{~g} \mathrm{ha}^{-1}+$ iodosulfuron-methylsodium $3.75 \mathrm{~g} \mathrm{ha}^{-1}$, (ii) aminopyralid $9.9 \mathrm{~g} \mathrm{ha}^{-1}+$ florasulam 4.95 $\mathrm{g} \mathrm{ha}^{-1}$, (iii) florasulam $3.75 \mathrm{~g} \mathrm{ha}^{-1}+2,4-\mathrm{D} 180 \mathrm{~g} \mathrm{ha}^{-1}$, and (iv) triasulfuron $6.15 \mathrm{~g} \mathrm{ha}^{-1}+$ dicamba $98.85 \mathrm{~g} \mathrm{ha}^{-1}$ gave good to excellent control by reducing weed density and/or biomass by more than $80 \%$ (Table 2).

Such acceptable levels of weed control could be attributed to the herbicides reaching seedlings and small weed plants at the early wheat tillering stage, to the susceptibility of most annual broadleaf weeds to herbicides, and to better growth conditions of weeds under irrigation. Previous studies revealed that many annual broadleaf weeds were controlled by broadleaf herbicides in wheat (Benahnia, 1985; Rafrafi, 1988; Errohi, 1995; Diab, 1996; Aitounejjar \& Tanji, 1997; Benslimane, 2000; Tanji, 2002; Tanji 2003; El Antri \& Madkouri, 2005). Further, Wu et al. (2010) reported in Australia that the efficacy of early postemergent applications of metsulfuron-methyl at $4.2 \mathrm{~g} \mathrm{ha}^{-1}$ on flaxleaf fleebane (Erigeron bonariensis L.) and it was effective up to $98 \%$. In Egypt, Saad et al. (2011) reported that tribenuron-methyl $\left(9.375 \mathrm{~g} \mathrm{ha}^{-1}\right)$ and flumetsulam $\left(5 \mathrm{~g} \mathrm{ha}^{-1}\right)+$ florasulam $\left(3.75 \mathrm{~g} \mathrm{ha}^{-}\right.$ $\left.{ }^{1}\right)$ reduced nettleleaf goosefoot (Chenopodium murale L.) density up to $91 \% 3$ weeks after treatment.

Due to foliar or root absorption and possibly the activation by irrigation, broadleaf herbicide treatments containing residual herbicides such as aminopyralid, iodosulfuron-methyl-sodium, and triasulfuron have been effective in controlling initial weed infestations as well as multiple flushes of weeds, and provided season-long control of weeds. But, use of residual herbicides might restrict the choice of crops planted after wheat. In North Dakota, USA, Mikkelson \& Lym (2011) found that residues of aminopyralid applied at $120 \mathrm{~g} \mathrm{ha}^{-1}$ injured alfalfa, soybean, and sunflower planted 8 and 11 months after treatments (MAT). They found that corn was not affected by aminopyralid when seeded 8 or 11 MAT and appeared to be the best cropping option for land recently treated with aminopyralid. 


\subsection{Weed control with grass + broadleaf herbicides}

Shoot weights of broadleaf weeds in untreated plots varied from 67 to $780 \mathrm{~g} \mathrm{~m}^{-2}$ (Table 3). Major weed species found in the trials were milk thistle (S. marianum), field marigold (C. arvensis), wild mustard ( $S$. arvensis), wild chicory (C. intybus), and blue pimpernel (L. arvensis).

Six herbicide treatments consistently provided excellent weed control by reducing weed biomass by $92-100 \%$ (Table 3 ). The other 6 treatments, including mesosulfuron-methyl + iodosulfuron-methyl-sodium, were excellent on many annual broadleaf weed species, but less effective against milk thistle ( $S$. marianum), as indicated by higher weed biomass (Table 3 ). In Portugal, Barros et al. (2009) found that premix of mesosulfuronmethyl at $12 \mathrm{~g} \mathrm{ha}^{-1}+$ iodosulfuron-methyl-sodium at $2.4 \mathrm{~g} \mathrm{ha}^{-1}$ gave satisfactory control of rigid ryegrass (Lolium rigidum), but had limited ability to control some broadleaf weeds such as night catchfly (Silene nocturna), Moroccan chamomile (Cladanthus mixtus), prostrate knotweed (Polygonum aviculare), blue pimpernel (Lysimachia arvensis), glandular plantain (Plantago afra), and Queen Anne's lace (Daucus carota).

\subsection{Grain yield after using broadleaf herbicides ( 3 trials)}

None of the broadleaf herbicide treatments visibly injured wheat at any location. Injury was not expected since the herbicide treatments were applied under appropriate growth conditions and at the registered rates. Grain yields in sprayed plots ranged from 7.8 to $8.0 \mathrm{~T} \mathrm{ha}^{-1}$ in trial $1,6.6$ to $6.9 \mathrm{~T}^{-1}$ ha in trial 2 , and 5.1 to 5.8 $\mathrm{T} \mathrm{ha}^{-1}$ in trial 3 (Table 2). In these trials, no significant differences were observed between yields obtained in various treated plots. Yield variations between trials and years were probably due to different preceding crops and irregular durations between irrigations. Yield increases due to weed control were 11, 13, and $71 \%$ compared to the yields observed in nontreated plots in trials 1,2 , and 3, respectively. Increased grain yields recorded in all herbicide-treated plots in comparison with untreated plots could be attributed to the excellent weed control by all herbicide treatments used in this study. Weed control improved grain yields through better utilization of available resources like water, fertilizer, sunlight, and space. Other appropriate practices that could have increased grain yield were November planting, certified seeds, disease control with fungicides, and irrigation (Hamid, 1995; Ezzahiri et al., 1999; Bouhache et al., 2000; Mosseddaq et al., 2000; Zbair et al., 2000). In on-farm trials, bread wheat grain yields varied with cultivars and were up to 7.8 $\mathrm{T} \mathrm{ha}^{-1}$ when the best production practices were used (Jlibene \& Chafai Elalaoui, 2002).

In untreated plots of all trials, grain yields were low compared to treated plots (Table 2). Yield losses due to weed competition throughout the growing season were 10,12 , and $41 \%$ compared to the highest yields observed in treated plots in trials 1, 2, and 3, respectively. Broadleaf weeds left in the nontreated plots appeared to cause significant crop production losses; hence, herbicide selection should be based on knowledge of weed species present within the weed flora. This is consistent with previous research that has emphasized the potential for bread wheat yield loss due to weed competition (Tanji, 2002). Curran et al. (2015) found that bread wheat yields declined 0.55 to $1.2 \mathrm{~kg} \mathrm{ha}^{-1}$ per $1 \mathrm{~kg} \mathrm{ha}^{-1}$ increase in hairy vetch (Vicia villosa Roth) biomass.

\subsection{Grain yield after using grass + broadleaf herbicides (5 trials)}

Grain yields in sprayed plots ranged from 6.5 to $6.8 \mathrm{~T} \mathrm{ha}^{-1}, 6.1$ to 6.5 $\mathrm{T} \mathrm{ha}^{-1}, 6.0$ to $6.5 \mathrm{~T} \mathrm{ha}^{-1}, 5.0$ to $9.3 \mathrm{~T} \mathrm{ha}^{-1}$, and 4.4 to $5.9 \mathrm{~T} \mathrm{ha}^{-1}$ in trials 1 to 5 , respectively (Table 3 ). The increased grain yields recorded in the herbicide treated plots in comparison with those of the untreated plots could be attributed to weed control, which resulted in reduced wheat competiton from weeds. Using the highest yields obtained in treated plots, grain yield increases due to weed control were $11,25,59,102$, and $44 \%$ compared to the yields observed in nontreated plots in trials 1 to 5 , respectively. Weed control with herbicides, as well as other appropriate practices, increased wheat grain yields (Ezzahiri et al., 1999; Bouhache et al., 2000; Mosseddaq et al., 2000; Zbair et al., 2000).

Grain yields were low in nontreated plots, as well as in treated plots where herbicide treatments failed to control milk thistle (trials 4 and 5, Table 3). Yield losses due to weed competition throughout the growing season were 10, 20, 37, 51, and $31 \%$ compared to the highest yields observed in treated plots in trials 1 to 5 , respectively. High yield loss $(51 \%)$ was due to milk thistle competition which drastically lowered grain yield in the untreated plots. Tanji (2002) reported that yield losses due to weed competition from the mixed populations of weeds were up to $80 \%$.

Herbicide treatments containing (i) pyroxsulam, (ii) mesosulfuron-methyl + iodosulfuron-methyl-sodium and (iii) mesosulfuron-methyl + iodosulfuron-methyl-sodium + diflufenican, caused severe injury symptoms on wheat during almost 2 months after treatments (data not shown). They caused an overall stunting and crop height reduction. However, the crop recovered later in the season with no yield reduction. It is highly possible that wheat injury was due to both mesosulfuron and pyroxsulam. Pyroxsulam at $18 \mathrm{~g} \mathrm{ha}^{-1}$ caused 5 to $10 \%$ wheat injury 5 to 14 days after treatment, but wheat recovered completely (Geier et al., 2011). Mesosulfuron-methyl at $15 \mathrm{~g}$ ai $\mathrm{ha}^{-1}$ with the crop safener at $30 \mathrm{~g}$ ai ha ${ }^{-1}$ injured wheat 11 to $32 \%$, but tiller number and height of treated wheat were, by 9 weeks after treatment, similar to those of nontreated wheat (Bailey et al., 
2004). Other studies revealed that wheat injury was often observed after application of mesosulfuron-methyl + iodosulfuron-methyl-sodium + safener, but injury did not reduce grain yield (Kirkland et al., 2001; Wiersma et al., 2003; Crooks et al., 2004a; Crooks et al., 2004b).

\section{Conclusion}

The results of this study indicate that very good control of most annual broadleaf weeds and high wheat yield can be achieved by the application of herbicide treatments containing 1 to 4 active ingredients at the early wheat tillering stage. Premix of grass and broadleaf herbicides were less effective on milk thistle ( $S$. marianum). Herbicide treatments containing pyroxsulam or mesosulfuron-methyl + iodosulfuron-methyl-sodium caused crop injury, but wheat plants recovered and grain yield was not affected. Further research involving grass and broadleaf herbicides is needed to explore ways, including the use of adjuvants, to avoid wheat injury and optimize herbicide efficacy on noxious weeds such as milk thistle.

\section{Acknowledgments}

This research work was conducted under the project "Enhancing Food Security in Arab Countries-Phase II". The authors would like to thank the Arab Fund for Economic and Social Development (AFESD), the Kuwait Fund for Arab Economic Development (KFAED), the Bill and Melinda Gates Foundation (BMFG) and the OPEC Fund for International Development (OFID) for their financial support and ICARDA for facilitating this study.

\section{Conflict of interest}

Authors would hereby like to declare that there is no conflict of interests that could possibly arise.

\section{References}

Aitounejjar A, Tanji A (1997) Chemical weed control, a means to increase the quality of mechanical harvesting of wheat. Al Awamia 96:47-53.

Bailey WA, Wilson HP, Brann DE, Griffey CA (2004) Wheat cultivar tolerance to AE F130060 031. Weed Technology 18:881886.

Barros JFC, Basch G, Freixial R, Carvalho M (2009) Effect of reduced doses of mesosulfuron methyl + iodosulfuron methyl sodium to control weeds in no-till wheat under Mediterranean conditions. Spanish Journal of Agricultural Research 7:905-912.
Benahnia K (1985) Influence of tillage and herbicides on weed control of irrigated bread wheat in Tadla. MS thesis, Hassan II Institute for Agronomy and Veterinary Medecine, Rabat, Morocco, Pp. 93.

Benslimane M (2000) Competitiveness of wheat varieties with broadleaf weeds. MS thesis, Hassan II Institute for Agronomy and Veterinary Medecine, Rabat, Morocco, Pp. 122.

Bouhache M, Rzozi SB, Taleb A, Sakhi M (2000) Effect of early weed control on wheat. Proceedings of the National Symposium on Weed Control in Cereals, Moroccan Association of Weed Science, Settat, Morocco, Pp. 93-98.

Crooks HL, York AC, Jordan DL (2004a) Tolerance of six soft red winter wheat cultivars to AE F130060 00 plus AE F115008 00. Weed Technology 18:252-257.

Crooks HL, York, AC, Jordan DL (2004b) Wheat tolerance to AE F130060 00 plus AE F115008 00 as affected by time of application and rate of the safener AE F107892. Weed Technology 18:841-845.

Curran WS, Wallace JM, Mirsky S, Crockett B (2015) Effectiveness of herbicides for control of hairy vetch (Vicia villosa) in winter wheat. Weed Technology 29:509-518.

Diab A (1996) Technical management of irrigated bread wheat in Tadla. MS thesis, Hassan II Institute for Agronomy and Veterinary Medecine, Rabat, Morocco, Pp. 117.

El Antri M, Madkouri M (2005) Mesosulfuron methyl + iodosulfuron methyl sodium: new post emergence herbicide registered for broadleaf and grass weed control in wheat in Morocco. In: Menendez J, Bastida F, Fernandez-Quintanilla C, Luis Gonzalez J, Recasens J, Royuela M, Verdu A, Zaragoza C (Eds.), Malherbologia Iberica y Magrebi: soluciones communes a problemas comunes, Universidad de Huelva, Huelva, Spain, Pp. $77-82$.

Errohi A (1995) Technical management of irrigated bread wheat in Tadla. MS thesis, Hassan II Institute for Agronomy and Veterinary Medecine, Rabat, Morocco, Pp. 136.

Ezzahiri B, Bouhache M, Zbair K (1999) Effect of herbicide and fungicide treatments in irrigated wheat. Proceedings of the Second Regional Symposium on Diseases of Cereals and Legumes, Nabeul, Tunisia, Pp. 447-454.

Geier PW, Stahlman PW, Peterson DE, Claassen MM (2011) Pyroxsulam compared with competitive standards for efficacy in winter wheat. Weed Technology 25:316-321. 
Hamid A (1995) Effect of supplementary irrigation and weeding on grain yield of bread wheat in Moulouya. MS thesis, National School of Agriculture of Meknes, Morocco, Pp. 113.

Jlibene M, Chafai Elalaoui A (2002) Wheat varieties adapted to North West Morocco. Agricultural Technology Transfer Bulletin, Rabat, Morocco, No 88.

Kirkland KJ, Johnson EN, Stevenson FG (2001) Control of wild oat (Avena fatua) in wheat with MKH6562. Weed Technology 15:48-55.

Mikkelson JR, Lym RG (2011) Aminopyralid soil residues affect crop rotation in North Dakota soils. Weed Technology 25:422429.

Mosseddaq F, Errohi A, Diab A (2000) Irrigated wheat in Tadla: efficiency and profitability of chemical weed control. Proceedings of the National Symposium on Weed Control in Cereals, Moroccan Association of Weed Science, Settat, Morocco, Pp. 6577.

Rafrafi M (1988) Weed control. 1. Chemical weed control in bread wheat (Triticum aestivurn L.) in Tadla, and 2. Chemical control of Bermuda grass (Cynodon dactylon (L.) Pers.) in sugar cane (Saccharum officinarum L.). MS thesis, Hassan II Institute for Agronomy and Veterinary Medecine, Rabat, Morocco, Pp. 168.

Rerhrhaye K, Ait El Mekki A (2017) Bread wheat production and food security in Morocco. Alternatives Rurales 5:1-17.

Saad ASA, Tayeb EHM, Masoud MA, Shawer RAA (2011) Comparative performance of wheat post-emergence herbicides in relation to their effect on wheat yield. Alexandria Science Exchange Journal 32:442-452.
Taleb A, Bouhache M, Rzozi SB (2000) Weeds associated with cereals in Morocco. Proceedings of the National Symposium on Weed Control in Cereals, Moroccan Association of Weed Science, Settat, Morocco, Pp. 1-9.

Tanji A (2000) Weed control in irrigated wheat and barley: situation in the irrigated perimeters in 1999-2000. Proceedings of the National Symposium on Weed Control in Cereals, Moroccan Association of Weed Science, Settat, Morocco, Pp. 79-92.

Tanji A (2002) Synthesis of 123 chemical weed control trials in bread wheat in Morocco from 1984 to 2001. Al Awamia 105:5783.

Tanji A (2003) Evaluation of herbicides in irrigated bread wheat in farmers' fields in the Tadla perimeter. Al Awamia 108:11-24.

Tanji A (2005) Field Guide to Weeds in Wheat and Barley in Morocco. National Institute for Agricultural Research, Rabat, Morocco, Pp.458.

Wiersma JJ, Durgan BR, Martinson KB (2003) Hard red spring wheat (Triticum aestivum) tolerance to postemergence grass herbicides. Weed Technology 17:297-301.

Wu H, Walker S, Robinson G, Coombes N (2010) Control of flaxleaf fleabane (Conyza bonariensis) in wheat and sorghum. Weed Technology 24:102-107.

Zbair K, Bouhache M, Ezzahiri B (2000) Weed and disease control in irrigated bread wheat. Proceedings of the Fourth Congress of the Moroccan Association for Plant Protection, Rabat, Morocco, Pp. 171-177. 